\title{
A Case of Respiratory Failure due to Smallpox Pneumonia
}

\author{
Su Çiçeği Pnömonisine Bağlı Solunum Yetmezliği Olgusu
}

Fatmanur Çelik Başaran', Nimet Aksel2 ${ }^{2}$, Mine Gayaf², Ayşe Özsöz², Dursun Tatar²

\begin{abstract}
Smallpox pneumonia is a rare complication of the smallpox infection. We present our case of required mechanical ventilation related to smallpox pneumonia in association with respiration failure. A 31 -yearold female applied to our emergency department due to cough, tachypnea, and a common papulovesicular skin rash as her radiological investigations bilateral nodular pulmonary infiltrates were diagnosed. She had a contact history, with her baby experiencing the smallpox disease. According to clinical and laboratory findings the case was diagnosed as smallpox pneumonia. Acyclovir $4 \mathrm{gr} /$ day p.o. antiviral management was initiated. At the second day severe dyspnea and cyanoses occurred and patient transferred to intensive care unit after intubation. After 48 hours with mechanical ventilation the patient extubated herself. After 15 days of acyclovir treatment a remarkable clinical and radiological recovery was observed. During smallpox disease symptoms of pneumonia and also possible hypoxemia must be closely monitored in order to prevent mortality due to respiratory failure.
\end{abstract}

Key words: Pneumonia, respiratory failure, smallpox.

\section{Özet}

Suçiçeği pnömonisi bu hastalığın seyri sırasında görülebilen nadir bir durumdur. Burada suçiçeği pnömonisi sonrası mekanik ventilasyon gerektiren ciddi bir solunum yetmezliği gelişmiş bir olguyu sunmaya çalışık. Otuz bir yaşında kadın hasta, hastanemizin acil servisine öksürük, apne, takipne ve yaygın papüloveziküler döküntü bulgularıyla başvurdu. Radyolojik incelemelerde bilateral nodüler dolgunluk izlendi. Hikâyesinde suçiçeği geçiren bebeği ile teması olduğunu anlattı. Klinik ve laboratuvar bulguları ile hastaya suçiçeği pnömonisi tanısı kondu. Hasta yatırılarak asiklovir 4 gr/gün tedavisi başlandı. Yatışının 2. gününde ciddi dispne ve siyanoz bulguları gelişmesi üzerine entübe edilerek yoğun bakım ünitesine alındı. Mekanik ventilasyon ile 48 saat tedavi sonrası hasta kendini ekstübe etti. Asiklovir tedavisi ile 15 gün sonra belirgin klinik ve radyolojik düzelme sağlandı. Suçiçeği hastalarında görülen pnömoni, gelişebilecek hipoksemi ve solunum yetmezliğine bağlı ölüm ihtimaline karşı yakından takip edilmelidir.

Anahtar Sözcükler: Pnömoni, solunum yetmezliği, suçiçeği.

may be correlated with death due to respiratory failure (1). In adults, smallpox pneumonia prevalence remains in the range of 0.25-1.8\%. In the most of the cases cough, fever, dyspnea, and tachypnea are the most common symptoms $(1,2)$.
Smallpox is an infectious disease caused by the varicella zoster virus. It is more commonly encountered during childhood and characterized with fever and skin rush. Smallpox pneumonia is one of the most severe complications of smallpox infection that is experienced during adolescence and
'Iğdır Devlet Hastanesi, Göğüs Hastalıkları Kliniği, Iğdır ${ }^{2}$ Dr. Suat Seren Göğüs Hastalıkları ve Cerrahisi Eğitim ve Araşıırma Hastanesi, Göğüs Hastalıkları Kliniği, İzmir

'Department of Chest Diseases, Iğdır State Hospital, Iğdır, Turkey ${ }^{2}$ Department of Chest Diseases, Dr. Suat Seren Chest Diseases and Thoracic Surgery Training and Research Hospital, İstanbul, Turkey

Submitted (Başvuru tarihi): 18.03.2015 Accepted (Kabul tarihi): 09.04.2015

Correspondence (iletişim): Fatmanur Çelik Başaran, Department of Chest Diseases, Iğdır State Hospital, Iğdır, Turkey

e-mail: fatmanner@hotmail.com 


\section{CASE}

A 31 -year-old female applied to our emergency department due to cough, fever, and chest pain for the previous three days. She had had a common papulovesicular skin rash, including on her scalp for one week. She had a contact history, with her child experiencing smallpox disease previously 15 days. She was a smoker $(10$ packet/year) for five years and had no history of any drug use, malignancy or any chronic disease.

During the physical examination, the patient was conscious, oriented, and cooperative. Her blood pressure was $90 / 60 \mathrm{mmHg}$, heart rate $128 / \mathrm{min}$, body temperature $38^{\circ} \mathrm{C}$, respiratory rate $20 / \mathrm{min}$, and oxygen saturation 85\%. A common papulovesicular rash was observed over her entire body (Figure 1). A respiratory system examination revealed mild cyanosis and tachypnea, and in auscultation, bilateral inspiratory rales were present. In cardiac auscultation there were no other abnormalities, except mild tachycardia.

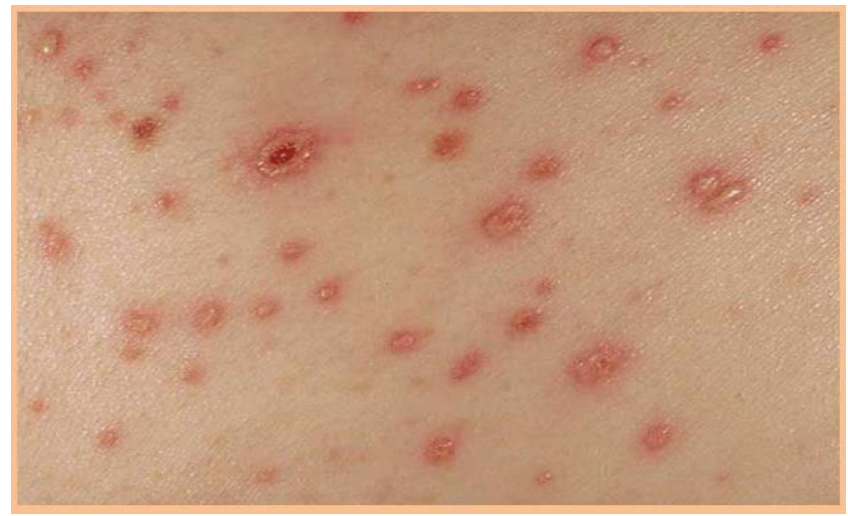

Figure 1: Papulovesicular skin lesions

The laboratory findings were: hemoglobin $11 \mathrm{~g} / \mathrm{dl}$, hematocrit 35\%, leukocyte $6000 / \mu \mathrm{L}$, platelets $240,000 / \mu \mathrm{L}$, alanine transaminase $47 \mathrm{U} / \mathrm{L}$, aspartate transaminase $48 \mathrm{U} / \mathrm{L}$, creatinine $0.76 \mathrm{mg} / \mathrm{dl}$, urea 22 $\mathrm{mg} / \mathrm{dl}$, sodium $133 \mathrm{mmol} / \mathrm{L}$, potassium $4 \mathrm{mmol} / \mathrm{L}$, and chloride $100 \mathrm{mmol} / \mathrm{L}$. Arterial blood gas analysis without oxygen support; $\mathrm{pH} 7.44, \mathrm{pO}_{2} 59 \mathrm{~mm} / \mathrm{Hg}, \mathrm{pCO}_{2} 33$ $\mathrm{mm} / \mathrm{Hg}, \mathrm{HCO}_{3} 22 \mathrm{mEq} / \mathrm{L}$, and oxygen saturation $92 \%$.

As per radiologic investigations, bilateral nodular pulmonary infiltrates were diagnosed (Figure 2-up). According to the clinical and laboratory findings, the case was diagnosed as smallpox pneumonia. Acyclovir $4 \mathrm{gr} /$ day p.o. antiviral management was initiated. On the second day of hospitalization, severe dyspnea and cyanoses with a decrease in oxygen saturations of till $58 \%$ occurred and patient transferred to the intensive care unit after intubation (Figure 2-mid). After 48 hours with mechanical venti- lation the patient extubated herself and remained in spontaneous respiration five more days in association with 2 $\mathrm{L} /$ min oxygen management. Oxygen saturation remained at $99 \%$ during the recovery period. After 15 days treatment with acyclovir remarkable clinical and radiological recovery was observed (Figure 2-down).

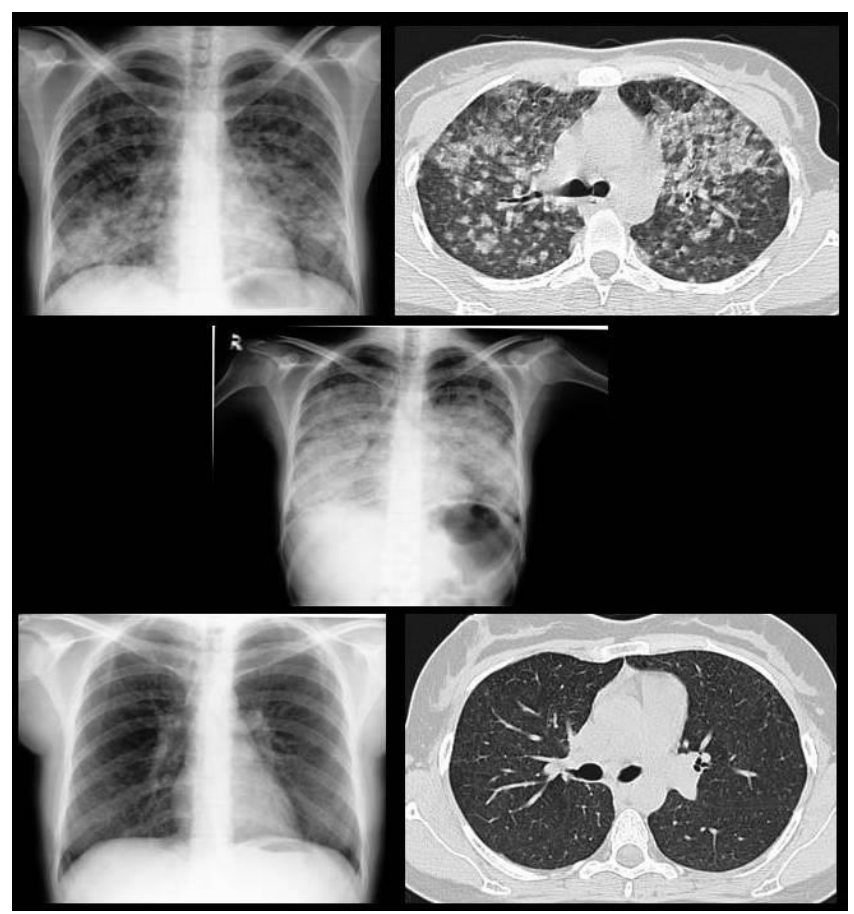

Figure 2: Chest $x$-ray and computer tomography of patient

\section{DISCUSSION}

In adults, nearly $75 \%$ of smallpox pneumonia occurs between the ages of 30 and 50 . The severity of these pneumonias varies from mild to fatal, due to severe respiratory failure (1). Progression to acute respiratory failure and $50 \%$ mortality rates may be seen especially in immune suppressive patients $(3,4)$. There are various risk factors for the progression of pneumonia during the primary varicella zoster virus infection: the development of respiratory symptoms, smoking, skin sing of more than 100, contact with a patient or a baby with smallpox, pregnancy, immune deficiency, chronic pulmonary disease, and the male gender $(1,5)$. Our case was an active smoker, had a history of contact, and a common rash but immune deficiency did not exist. There is nothing in her anamnesis that can cause immune deficiency such as chronic disease, malignancy, chronic use of drug and etc. Symptoms and signs of varicella pneumonia appear one to six days after the appearance of skin lesions (6). Patients have the symptoms including cough, hemoptysis, chest pain, dyspnea, while severe cases may have respiratory insufficiency and cyanosis $(1,6)$. In our case, 
symptoms of cough, fever, chest pain and dyspnea also occurred four days after the appearance of skin eruptions. Respiratory insufficiency was detected on admission.

The typical radiological appearance of varicella pneumonia is well-circumscribed nodular opacities $5-10 \mathrm{~mm}$ in diameter and consolidations formed by the congregation of these nodules. These lesions are prominent around the hilum and in bases. Hilar lymphadenomegaly and pleural effusion are rarely seen (1). These lesions generally begin to disappear one week after the healing of the skin eruptions. Radiological changes may sometimes persist for months. In some cases, bilateral widespread calcifications of 2-3 $\mathrm{mm}$ in diameter may persist as a sequel. These radiological findings, together with skin lesions, are usually diagnostic $(1,7,8)$. Our case also had a similar radiological appearance on admission.

The mortality rate of varicella pneumonia is $15 \%$. Various studies have reported that the early initiation of acyclovir treatment might be lifesaving by preventing this severe complication of varicella $(1,4)$. Early treatment is defined as the treatment commenced within the first 36 hours in immunocompetent adults aged above 18 years and who have been hospitalized for radiologically evident pneumonia (1). The recommended dose of intravenous acyclovir treatment for pregnant patients with severe complications and patients with a weak immune response is 10 $\mathrm{mg} / \mathrm{kg}$ every 8 hours. Famciclovir and valacyclovir have proven efficacious for the treatment of adult herpes zoster infections. Acyclovir-resistant VZV infections may be treated with foscarnet (9). In our case, we also achieved a complete response using oral acyclovir tablets at a dose of $5 \times 800 \mathrm{mg}$.

Mohsen et al. (10) analyzed 46 studies and compared cases with acyclovir treatment and cases without acyclovir treatment. They reported that the mortality rate was 3.6times higher in the group without treatment. Varicella pneumonia related deaths usually occur due to respiratory insufficiency in patients who need intensive care follow up and mechanical ventilation. Findings other than hypoxia were reported to be weak indicators of disease severity for these cases (11). It is also not possible to predict which cases will need mechanical ventilation support (12). For this reason, close follow-up of the patients with pulse oximeter and arterial blood gas analysis is important. In our case, we performed arterial blood gas follow up after the confirmation of hypoxia with pulse oximeter and arterial blood gas analysis. In the studies, it was reported that oxygen support via oxygen masks, noninvasive respiratory support and invasive respiratory sup- port in those cases that failed to respond non-invasive respiratory support, may be used for respiratory insufficiency, based on the clinical status of the patient (11). Despite medical treatment and oxygen support, our case was intubated in the inpatient clinic due to deterioration in arterial blood gas and consciousness. After selfextubation in the 48th hour of mechanical ventilation, the patient did not need further invasive or non-invasive mechanical ventilation. The patient did not require intensive care unit follow up after the tenth day and discharged on the seventh day with complete healing.

In conclusion, adult cases with varicella infection and respiratory symptoms need particular attention. Cases with hypoxia must be closely followed for respiratory insufficiency.

\section{CONFLICTS OF INTEREST}

None declared.

\section{AUTHOR CONTRIBUTIONS}

Concept - F.Ç.B., N.A., M.G., A.Ö., D.T.; Planning and Design - F.Ç.B., N.A., M.G., A.Ö., D.T.; Supervision F.Ç.B., N.A., M.G., A.Ö., D.T.; Funding - N.A., D.T.; Materials - F.Ç.B., M.G., A.Ö.; Data Collection and/or Processing - F.Ç.B.; Analysis and/or Interpretation - N.A., M.G.; Literature Review - F.Ç.B.; Writing - F.Ç.B.; Critical Review - N.A., M.G., A.Ö., D.T.

\section{YAZAR KATKILARI}

Fikir - F.Ç.B., N.A., M.G., A.Ö., D.T.; Tasarım ve Dizayn - F.Ç.B., N.A., M.G., A.Ö., D.T.; Denetleme - F.Ç.B., N.A., M.G., A.Ö., D.T.; Kaynaklar - N.A., D.T.; Malzemeler - F.Ç.B., M.G., A.Ö.; Veri Toplama ve/veya İsleme - F.Ç.B.; Analiz ve/veya Yorum - N.A., M.G.; Literatür Taraması - F.Ç.B.; Yazıyı Yazan - F.Ç.B.; Eleştirel İnceleme - N.A., M.G., A.Ö., D.T.

\section{REFERENCES}

1. Kunduracioglu A, Ayik S, Ozsoz A, Cakan A. Chickenpox Pneumonia. Turkish Thorac J 2009; 10:190-2.

2. Whitley RJ. Varicella zoster virus. In: Mandell, Bennett, Dolin, eds. Principles and Practice of Infectious Disease. 4th ed. New York: Churchill Livingstone, 1995:1345-50.

3. Alanezi M. Varicella pneumonia in adults: 13 years' experience with review of literature. Ann Thorac Med 2007; 2:163-5. [CrossRef]

4. Voore N, Lai R. Varicella pneumonia in an immunocompetent adult. CMAJ 2012; 184:1924. [CrossRef] 
5. Heininger U, Seward JF. Varicella. Lancet 2006; 368:1365-76. [CrossRef]

6. Tunbridge AJ, Breuer J, Jeffery KJ; British Infection Society. Chickenpox in adults-clinical management. J Infect 2008; 57:95-102. [CrossRef]

7. Raider L. Calcification in chickenpox pneumonia. Chest 1971; 60:504-7. [CrossRef]

8. Fraser RG, Freaser RS, Pare JAP, Pare PD, Generics GP. Diagnosis of Diseases of the Chest. 4th ed. Philadelphia: Saunders, 1999:2507.

9. Smego RA Jr, Asperilla MO. Use of acyclovir for varicella pneumonia during pregnancy. Obstet Gynecol 1991; 78: $1112-6$
10. Mohsen AH, McKendrick M. Varicella pneumonia in adults. Eur Respir J 2003; $21: 886-91$. [CrossRef]

11. Troya García J, Espinosa de Los Monteros Garde MJ, Moreno B. Varicella pneumonia in adult population: review of 21 cases (In Spanish). Rev Clin Esp 2006; 206:566-9.

12. Özbay B, Sertoğullarından B. Varicella pneumonia requiring invasive mechanical ventilation. Tuberk Toraks $2011 ;$ 59:259-62. [CrossRef] 